\title{
Sustainability and Water Consumption Rationalization in the Hotel Sector: Applied to Five-Star Hotels in Hurghada
}

\author{
Maisa Fathey Abd El-Latief \\ Mahmoud Ahmed Mohamed Saleh \\ Higher Institute for Tourism and Hotels - Luxor (E.G.O.T.H)
}

\begin{abstract}
The city of Hurghada is one of the most important tourist attractions on the local and international levels, Due to its natural and human characteristics, which are considered attractive factors for tourist activity. Views of the importance of the hotel sector and its impact on the environment, most of the international hotels tend to rationalize water consumption as a requirement of development in the hotel sector. The aim of this study is to identify the extent to which hotels in Hurghada are committed and raising awareness among decision makers and employees to rationalize water consumption. The study community consisted of (25) five star hotels in Hurghada. The Questionnaires were distributed to managers and heads of (25) hotels, while twenty-two questionnaires were accepted but three were rejected. In light of the results of the study has reached a number of recommendations, including awareness rising for all employees of the hotel, rationalizing the proper use of water and various rationalization methods, as well as training courses for all sections of the hotel in rationalizing the use of water. In all parts of the hotel, the best means should be used to support the application of best environmental practices within the hotels and interest in spreading awareness of the rational use of water and rationalization methods through various media.
\end{abstract}

Keywords: Rationalization, Environmental Practices, Development, Awareness, Hurghada City.

\section{Introduction}

Bohdanowicz et al. (2005) said that with the growing environmental degradation, sustainable development, including the development of a more sustainable built environment, has become a vital priority today. Mensah (2006) added that several factors indicate that the hotel industry has an important responsibility in this process. Tang (2012) said that within the hotel sector, the areas of concern for the environment include recycling of waste, waste management, clean air, energy and water conservation, environmental health, maintenance of permits such as building permits and compliance with legislation, purchasing policy and environmental education.

Water is a natural and important source for tourism, necessary for the basic human needs and various entertainment activities, it's important especially in hotels for operations that consume a large amount of water like (outdoor swimming pools, indoor swimming pools, Jacuzzi, gardens, washing machine, dishwashers and other facilities) (Untaru et al., 2016). In hotels the excessive consumption for water has environmental damages which are one of the important challenges that face the industrial hospitality (Gabarda et al., 2017).

Tourism and travelling are known to be the most water-consuming sectors especially the hostels and hospitality sector where the degree of consumption of this important source carries depending on the type, location, classification, size, organizational structure and consumer policy adopted by its management in the field of water in one hand and the level of awareness that the hotel's guests have in this direction (Scott et al., 2009). The increase in demands for potable water and waste water consumption due to the lack/low environmental awareness of tourists led to an increase in the quantity of sewage water, pressure on the treatment systems or exceeding their capacity and the exit of semi-treated water that discharged on the marine environmental or in the bottom of valleys and may reach to groundwater (United Nations World Tourism Organization (UNWTO), 2013). 
Hotels are one of the most water consuming sectors where water consumption exceeds the local population, three times the amount of water consumed by the resident (Eurostat, 2009). Water consumption in hotels is not limited to the water required for the necessary needs of the guest but extends to the water required for public works to operate the hotel, there are several reasons behind the increase in the daily consumption of water, especially five-star hotels, including water used in cleaning up the guests' rooms, kitchens, laundry, public baths in hotels, swimming pools, irrigate gardens, restaurants and health clubs (Page et al., 2014).

The statistics clearly indicated the high consumption of water in hotels for a number of reasons, including: the weakness of programs for this consumption or its lack and the need for clear controls and conditions imposed by the authorities concerned, the most important awareness and guidance directed to the guests and the employees in the hotel, the high temperature in the Summer season accelerates the process of water evaporation in swimming pools, water fountains, etc. (Millar and Balogu, 2011). That requires a quick reconsideration of consumer water policies within the hotel. Therefore, the hotels management must develop strategies and plans to consumption by informing the guests about the importance of water conservation and trying to convince them to modify their behavior and return to the optimum use of water during their stay at the hotel (Page et al., 2014). In addition, the management of the hotel has to establish controls to reduce water consumption by applying and setting up the so-called green practices and effective management of water conservation, such as installing of a low-flow toilets, shower heads, taps and sanitary pieces using water-flow reduction technology to rationalize water consumption (Baker et al., 2014). The reuse of towels by hotels' guests is one of the best examples of reducing the water consumption of the hotel (Untaru et al., 2016).

Raising the awareness of the hotels' guests and employees about rationalization of water is an important step in reducing water consumption, which is effective not only in water consumption but also in reducing the energy bill because of pumping and heating less water and increasing recycling efficiency for heating purposes (Singh et al., 2014). Reducing water consumption will lead to lower processing costs as well as capital costs due to fewer pumps and water heaters. Hospitality researchers have confirmed that consumer behavior in terms of optimal water use is of prime importance in terms of the economic feasibility of rationalizing the water consumption used during their stay in the hotel (Choi et al., 2015). The statistics indicated that the droplets of water leaking from the faucet waste nearly 40001 of drinking water per year (Untaru et al., 2016).

\section{Objectives of the study}

- Knowing the opinions and directions of the hotel employees of the five-star hotels about the importance of rationalizing water consumption.

- Identifying procedures and practices used to rationalize water consumption.

- Enhancing the environmental concept for the staff and decision-makers in the five-star hotels with the necessary of rationalize water consumption.

- Knowing the opinions and directions of the hotel employees towards hotel commitment to implement water consumption strategies.

- Recognizing the negative effects of increased water consumption in Hurghada hotels.

- Identifying the obstacles and difficulties facing hotels in the application of modern methods to reduce water consumption. 


\section{Study's literatures}

Water rationalization is an effective measure to reduce water consumption and conservation (Marandu et al., 2010). The water consumption in the hotel sector has become one of the economic and environmental constraints due to the scarcity of this important resource, the researchers agreed that one of the most important policies that must be taken into consideration by the hotel management is to educate guests about the importance of rationalizing water and directing their behavior to reducing water consumption and some examples of this are the application of the reuse program for towels and beds sheets by informing the guest about the amount of water consumed in washing towels, sheets and blankets that were used just once (Mensah and Mensah, 2013). It explained that water scarcity raises the challenges of local communities and also has an utmost importance to start the activity in the hospitality sector (Hwang and Lee, 2018). It is not possible to operate any hotel without the availability of the water source. Water plays an important role in the daily operation of the hotel. Hotels depend on the availability of water at an appropriate quality to contribute at a high levels water is used and consumed by everyone who works or stays at the hotel (Han et al., 2018).

The total number of 5 stars' hotels in the city of Hurghada (25) hotels in 2019. In order to achieve the research objectives, a questionnaire was prepared for the general managers or environmental/ maintenance managers of five stars' hotels in Hurghada. A comprehensive survey was conducted on all hotels in Hurghada, a number (22) of hotels were answered, while, managers of (3) hotels were refused to fill questionnaire (equivalent to $88 \%$ of all hotels). Across the countries of the world, water scarcity is triggering growing concern and an acceleration of efforts to solve the water troubles. Therefore, identification of the determinants of water consumption of hotel services is essential for a better thoughtful of water conservation (Meade and Gonzalez-Morel, 2011).

Water scarcity is a global issue and Egypt is addressing it. The global average for water stress is $11 \%$ (the average level at which a country withdraws its fresh water from its available resources); however, 31 countries' water stress level ranges between 25\%. Sixteen desalination plants will have been built or upgraded in 2018-2020: Water treatment and desalination are not exactly uncharted waters to Egypt. The country already embarked on such projects using many systems. Egypt targets the production of $700,000 \mathrm{cbm} /$ day of desalinated water by the end of 2020 , up from the current 250,000cbm/day. To achieve this target, Egypt plans on adding/upgrading 15 water desalination plants in five governorates: Matrouh, North Sinai, South Sinai, Red Sea, and Port Said, which — with the Hurghada project-have a combined capacity of $553,000 \mathrm{cbm} /$ day, this is illustrated in table (1) (Ahram Gate, 2019).

Table 1: Future water desalination project in Egypt

\begin{tabular}{|c|c|}
\hline Location & cbm/day \\
\hline Port Said & 170,000 \\
\hline \multirow{2}{*}{ Matrouh } & 150,000 \\
\hline & 34,000 \\
\hline Hurghada & 80,000 \\
\hline Red Sea governorate & 47,000 \\
\hline South Sinai & 42,000 \\
\hline North Sinai & 30,000 \\
\hline Total added capacity & 553,000 \\
\hline Current desalination plants production & 140,000 \\
\hline Desalination capacity after the addional plants & 693,000 \\
\hline $\begin{array}{l}\text { Target total production from current and future } \\
\text { desalination plants }\end{array}$ & 700,000 \\
\hline
\end{tabular}


Five stars' hotels have been selected for the following reasons, as Marta and David (2015) explained, the differences in water consumption between the five hotel categories analyzed for the different years considered. The $5 \mathrm{H}^{*}$ group showed the largest variety of water consumption uses and offered a greater diversity of services and water-intensive facilities, all leading to higher water consumption. Analysis does not control for hotel size or occupation. Overall occupancy in the last six years had increased considerably (in the order of $10 \%$ ) for $5 \mathrm{H}^{*}$ hotels and even more for $4 \mathrm{H}^{*}$ hotels, but remained relatively stable for smaller categories, we may recommend that our fourth finding is relatively robust. The higher class hotels are more likely to adopt water-saving measures than the rest. This is reasonable since $5 \mathrm{H}^{*}$ hotels have more water intensive facilities and tend to be better in size, they use more water to run their daily activities. Figure 1 shows a sustained decrease in water consumption by the $5 \mathrm{H}^{*}$ group category in the ten years study. In light of these results, the sustained downward trend shown by the $5 \mathrm{H}^{*}$ segment - and not found in any other hotel category segment - suggests the possibility that $5 \mathrm{H}^{*}$ hotels adopted relatively more significant water conservation measures and/or practices. We cannot however account for, and rule out, the effects of outsourcing (more likely for higher class hotels) that is shows at analysis in figure 1.

Figure. 1: The differences in water consumption between the five hotel categories

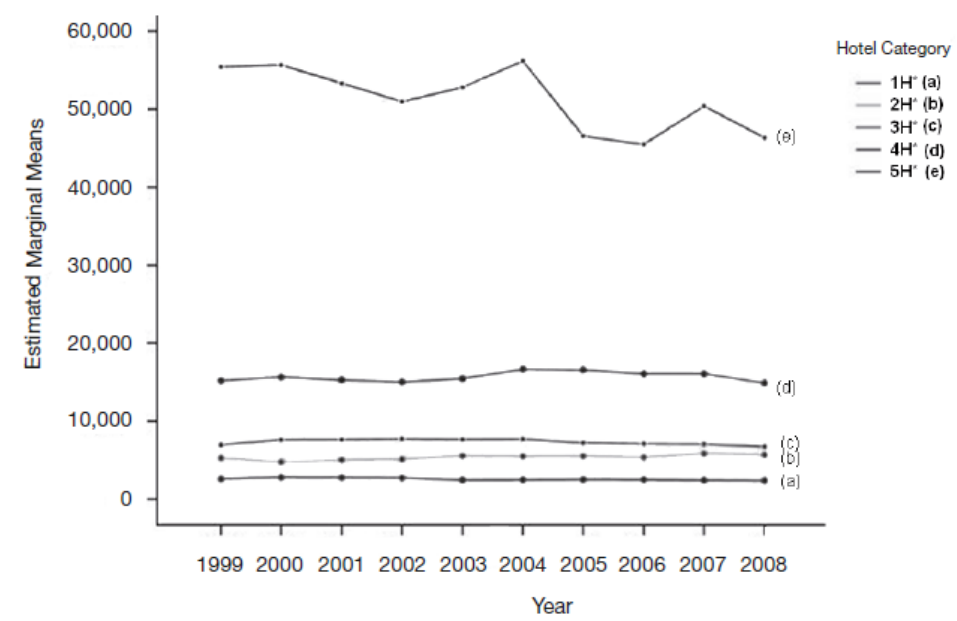

Water consumption rates in hotels

Hoffman (2006) pointed out that the guest consumption of water per night varies from one country to another. Some countries have very limited use of water compared to other countries where water consumption is very high. For example, in France and Spain consumption rates of water is fairly lowlife compared to other. The guest consumption per night in the hotel is 981 liters per guest in Philippines. China comes the second with 956 liters per guest (Gössling et al., 2011). Malaysia with a water consumption of 914 liters per resident while the tourist consumes in Egypt 717 liters per night on average, nearly four times that of Spain. Hotels decision-makers must take the necessary measures and managements to treat the pressure of consuming large amounts of water to reduce the cost of the resident staying and maintaining these important resources (Silva-Afanson et al., 2011). The importance of rationalizing the consumption of water in hotels. Water saving does not only mean reducing the water bill or reducing the amount of wastewater, but also reducing the energy bill by plumbing and heating less water and increasing the efficiency of recycling for heating purposes. Water supply will reduce processing costs and capital costs due to the reduction in the number of pumps and water heater. Water efficiency helps manage the hotels business and provide water for future needs as well (Wyngaard and deLange, 2013). Each water drop provided increases the opportunity to provide other consumers 
with much needed quantities. And also the provision of water contributes to its sustainability and this responsibility lies on the public and private sectors and all members of society (Gossel et al., 2014).

Figure 2: Litres per person per day

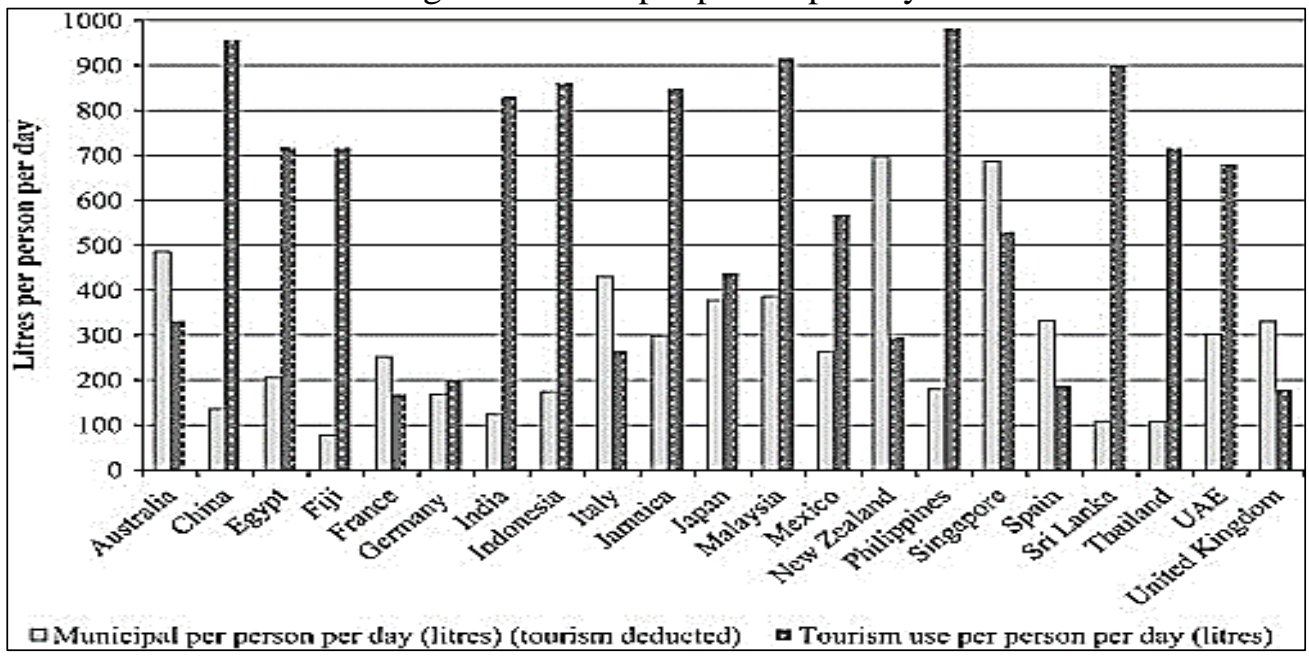

Figure 3: Water Disparity

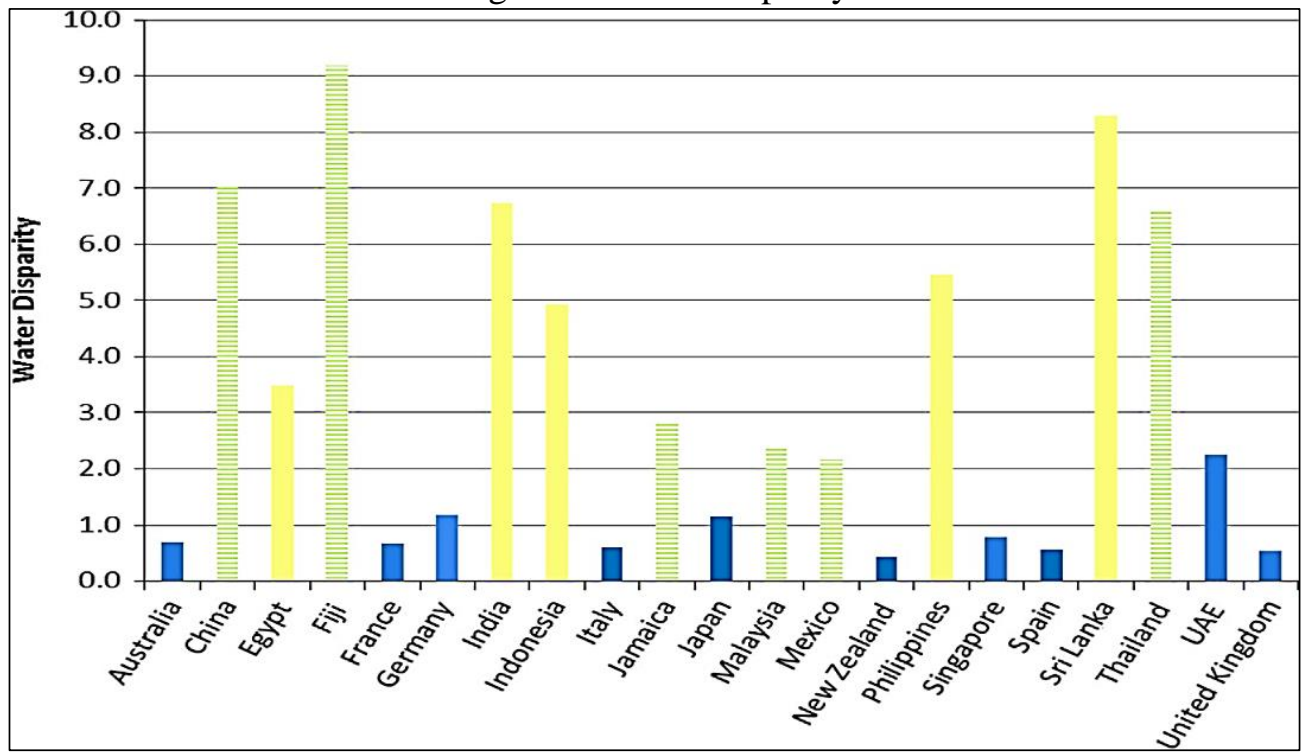

\section{Management of water conservation and recycling in hotels}

Water reclamation and recycling in the various operations of the hotel are important, therefore, hotels must follow effective strategies to reduce water consumption and reuse them to be used again in many different operations, which is called "green practices" (Wyngaard and de Lange, 2013). The water consumption of the rooms occupied by the hotel is very important because the amount of water consumed in this sector of the hotel doesn't have fixed rates because they are in continuous increase (Singh et al., 2014).

In general, most cases of hotel guests' use of water are associated with such behaviors as changing used towels, bathing, changing linens and bedspreads, water flow in toilets and washing teeth, ect. (Mensah and Mensa, 2013; Becken et al., 2013). Therefore, the massive water consumption used during the stay of the hotel guests' can be minimized by effectively managing water conservation, thereby reducing these impacts to a minimum (Baker et al., 2014). The most effective programs that can be applied to reduce water consumption are the reuse of towels, bed 
linens, shower heads, latrines and urinals, which are effective strategies for obtaining best practices that lead to rationalization and preservation on water (Gabarda-Mallorgni et al., 2017).

According to (Bacot et al., 2002), researchers agreed that rationalizing water consumption and reprocessing whether wastewater or consumed water by other facilities within the hotel, would not only reduce environmental risks but also have economic benefits (Barberán et al., 2013). A successful management, which implements water conservation and reuse strategies and programs, brings direct benefits (such as material benefits by reducing waste water pollution and saving costs for recycling) as well as indirect benefits (for example, guests feel satisfied during their stay in the hotel because they live in a clean environment, to improve the ability to compete (Singh et al., 2014).

\section{Methodology}

\section{Research Instrument}

The field study accomplished through survey by personal visits, networks and emails through October 2018 to April 2019. The questionnaire also aimed to assess the degree of awareness of employees in the hotel sector about sustainability in the hotel sector and rationalization of water consumption. The questionnaire also dealt with general data about the hotel, its facilities and water sources in the hotel and how it is consumed and rationalized in each section of the hotel. The survey included (25) hotels of the five star hotels in Hurghada. While, the number of (22) questionnaires was filled. Questionnaire was evaluated using a five-point likert scale ranging from $1=$ 'never' to 5= 'always'. Finally, socio-demographic and general questions such as: Age, education and experience, in addition to, general information about the respondents' sustainability and water consumption rationalization in the hotel sector, were included also in the questionnaire.

\section{Questionnaire pre-testing}

To increase the reliability and validity of the questionnaire and to measure its attributes' adequateness, clearness and ease of understanding, the English questionnaire is reviewed by some academic scholars.

\section{Data Analysis}

Accordingly to the data collected from questionnaire form, statistically and analyzed by using the statistical package per social science (SPSS/ version 20.0) software. The percentage had been calculated to classify the sets and determine how homogenous or in consistent the sample was regards to all study variables.

\section{Results and Discussion}

The responses obtained from the directed questionnaires are shown as follows:

Table (2) illustrated that all study group aged more than 35 years old, and had higher education, with experience duration more than 10 years.

Table 2: Description of demographic characters among study group

\begin{tabular}{|l|c|c|}
\hline \multicolumn{1}{|c|}{ Variables } & \multicolumn{2}{c|}{ Number (n=22) } \\
\hline Age groups & 0 & $0 \%$ \\
\hline Less than 25 years old & 0 & $0 \%$ \\
\hline 25-35 years old & 22 & $100 \%$ \\
\hline More than 35 years old & 0 & $0 \%$ \\
\hline Educational level & 22 & $100 \%$ \\
\hline Intermediate level & 0 & $0 \%$ \\
\hline Higher education & & \\
\hline Postgraduate & & \\
\hline
\end{tabular}




\begin{tabular}{|l|c|c|}
\hline Years of experience \\
\hline Less than 5 years & 0 & $0 \%$ \\
\hline 5-10 years & 0 & $0 \%$ \\
\hline More than 10 years & 22 & $100 \%$ \\
\hline
\end{tabular}

1. Internal use of water

a. Operations, water control and procedures for maintenance of water lines and networks.

b. Measures taken to rationalize water consumption in rooms.

c. Internal supervision.

d. Laundry.

e. Kitchen.

Table 3 illustrates that more than half of hotel managers mentioned that they always apply the operations for water control and procedures for maintenance of water lines and networks as around $50 \%$ to $80 \%$ of them said they always do maintenance to water supply system, providing technicians and natural resources for maintaining, Using techniques to discover and repair water leak, improving the efficiency of the system design, regular checking up, monitoring water consumption, evaluating the efficiency system, apply the technique of low pressure, water recycle, install waste water, seawater, heaters, aeration system, separate water meter for high water consumption, measure laundry water use, raise awareness about water conservation for workers and guests, proper management of water leakage, and inspect fire extinguisher, but higher percentage of them mention that they often keep maintenance schedule.

Water use in each end-use is likely to be influenced by its major operational activities. There were a number of reasons for upper water consumption in hotel sector, including the hotel running activities such as daily room cleaning, daily laundry and repairs of swimming pools, maintenance of grounds (irrigation), etc. (Deng and Burnett, 2002). Moreover, water intensive nature of services provided by the hotel also leads to huge water consumption (Bohdanowicz and Martinac, 2007).

Charara et al. (2011) said that efficient use of water in water intensive operations will result in reducing the hotel water consumption and saving water. Leaks are an example for inefficient practice and may be significant contributor to hotel water consumption based on the time taken to rectify those leaks. As mentioned, poorly maintained toilets such as toilets with leaking flapper valves, overflowing tanks or defective flush mechanisms can waste a significant amount of water. Corrective and preventative maintenance practices also enable a hotel to reduce the unnecessary wastage of water and reduce its total water consumption. Meade and GonzalezMorel (2011) added that maintenance activities also affect the total water consumption of a hotel facility. Conservation opportunities are related to both equipment measures involving replacement or significant upgrades to existing equipment, as well as individual and behavioral measures related to equipment maintenance and to member of staff/guest education. However, behavioral measures also should be given an attention in order to motivate the occupants to behave in a sustainable manner so that the hotel water consumption can be minimized.

Table 3: Frequency of different response about Operations, water control and procedures for maintenance of water lines and networks

\begin{tabular}{|c|c|c|c|c|c|c|c|}
\hline \multirow{2}{*}{ Items } & Never & Seldom & Sometimes & Often & Always & \multirow{2}{*}{ Mean } & \multirow{2}{*}{ S.D } \\
\hline & No. (\%) & No. $(\%)$ & No. (\%) & No. (\%) & No. (\%) & & \\
\hline $\begin{array}{l}\text { 1. Maintenance of water supply } \\
\text { system to reduce water loss ratio. }\end{array}$ & $0(0)$ & $0(0)$ & $0(0)$ & $8(30.8)$ & $\begin{array}{c}18 \\
(69.2)\end{array}$ & 4.75 & 0.43 \\
\hline $\begin{array}{l}\text { 2. Providing technicians and natural } \\
\text { resources for maintaining }\end{array}$ & $0(0)$ & $0(0)$ & $0(0)$ & $8(30.8)$ & $\begin{array}{c}18 \\
(69.2) \\
\end{array}$ & 4.76 & 0.43 \\
\hline
\end{tabular}




\begin{tabular}{|c|c|c|c|c|c|c|c|}
\hline \multirow{2}{*}{ Items } & Never & Seldom & Sometimes & Often & Always & \multirow{2}{*}{ Mean } & \multirow{2}{*}{ S.D } \\
\hline & No. $(\%)$ & No. $(\%)$ & No. (\%) & No. $(\%)$ & No. (\%) & & \\
\hline \multicolumn{8}{|l|}{$\begin{array}{l}\text { connections and ware for } \\
\text { determining and maintaining any } \\
\text { water leak. }\end{array}$} \\
\hline $\begin{array}{l}\text { 3. Using techniques to discover and } \\
\text { repair water leak. }\end{array}$ & $0(0)$ & $0(0)$ & $0(0)$ & $5(19.2)$ & $21(80.8)$ & 4.84 & 0.36 \\
\hline $\begin{array}{l}\text { 4. Improving the efficiency of the } \\
\text { system design to prevent high water } \\
\text { pressure. }\end{array}$ & $0(0)$ & $0(0)$ & $0(0)$ & 7 (26.9) & $\begin{array}{c}19 \\
(73.1)\end{array}$ & 4.78 & 0.41 \\
\hline $\begin{array}{l}\text { 5. Regular checking up and } \\
\text { maintenance of water appendices and } \\
\text { the lines of hot water leakage. }\end{array}$ & $0(0)$ & $0(0)$ & $0(0)$ & 9 (34.6) & $\begin{array}{c}17 \\
(65.4)\end{array}$ & 4.69 & 0.47 \\
\hline $\begin{array}{l}\text { 6. Monitoring water consumption in } \\
\text { all areas at the hotel. }\end{array}$ & $0(0)$ & $0(0)$ & $0(0)$ & 9 (34.6) & $17(65.4)$ & 4.57 & 0.50 \\
\hline $\begin{array}{l}\text { 7. Checking all water meter to } \\
\text { guarantee its accuracy in measuring } \\
\text { water consumption. }\end{array}$ & $1(3.8)$ & $0(0)$ & $0(0)$ & $\begin{array}{c}10 \\
(38.5)\end{array}$ & $\begin{array}{c}15 \\
(57.7)\end{array}$ & 4.42 & 0.83 \\
\hline $\begin{array}{l}\text { 8. Monitoring water supply and } \\
\text { evaluating the efficiency system at } \\
\text { the hotel. }\end{array}$ & $0(0)$ & $0(0)$ & $0(0)$ & $10(38.5)$ & $\begin{array}{c}16 \\
(61.5)\end{array}$ & 4.60 & 0.49 \\
\hline $\begin{array}{l}\text { 9. Applying the technique of low } \\
\text { pressure on water meter system. }\end{array}$ & $0(0)$ & $0(0)$ & $0(0)$ & $5(19.2)$ & $\begin{array}{c}21 \\
(80.8)\end{array}$ & 4.81 & 0.39 \\
\hline $\begin{array}{l}\text { 10. Reuse of water resulted from } \\
\text { laundry, shower and drainage. }\end{array}$ & $0(0)$ & $2(7.7)$ & $0(0)$ & 9 (34.6) & $\begin{array}{c}15 \\
(57.7)\end{array}$ & 4.39 & 0.99 \\
\hline $\begin{array}{l}\text { 11. Installing waste water treatment } \\
\text { plants for irrigating parks and } \\
\text { gardens. }\end{array}$ & $1(3.8)$ & $0(0)$ & $0(0)$ & 7 (26.9) & $\begin{array}{c}18 \\
(69.2)\end{array}$ & 4.57 & 0.79 \\
\hline $\begin{array}{l}\text { 12. Installing seawater desalination } \\
\text { plants for daily use. }\end{array}$ & $0(0)$ & $0(0)$ & $0(0)$ & 9 (34.6) & $\begin{array}{c}17 \\
(65.4)\end{array}$ & 4.69 & 0.46 \\
\hline $\begin{array}{l}\text { 13. Installing separate water meter } \\
\text { for high water consumption areas. }\end{array}$ & $1(3.8)$ & $0(0)$ & $0(0)$ & $\begin{array}{c}12 \\
(46.2)\end{array}$ & $13(50)$ & 4.39 & 0.78 \\
\hline $\begin{array}{l}\text { 14. Installing heaters and hot water } \\
\text { insulating pipes. }\end{array}$ & $0(0)$ & $0(0)$ & $0(0)$ & $13(50)$ & $13(50)$ & 4.51 & 0.56 \\
\hline $\begin{array}{l}\text { 15. Measuring hot and cold water } \\
\text { used in laundry. }\end{array}$ & $0(0)$ & $0(0)$ & $0(0)$ & $\begin{array}{c}12 \\
(46.2)\end{array}$ & $\begin{array}{c}14 \\
(53.8)\end{array}$ & 4.51 & 0.66 \\
\hline $\begin{array}{l}\text { 16. Installing aeration systems in } \\
\text { different areas at the hotel. }\end{array}$ & $1(3.8)$ & $1(3.8)$ & $0(0)$ & $5(19.2)$ & $\begin{array}{c}19 \\
(73.1)\end{array}$ & 4.56 & 0.91 \\
\hline $\begin{array}{l}1^{\vee} \text {. Training workers on determining } \\
\text { and reporting if there is a problem } \\
\text { in plumping (such as toilets, faucets } \\
\text { and shower heads). }\end{array}$ & $0(0)$ & $0(0)$ & $0(0)$ & $6(23.1)$ & $\begin{array}{c}20 \\
(76.9)\end{array}$ & 4.60 & 0.78 \\
\hline $\begin{array}{l}\text { 1^. Protecting maintenance schedule } \\
\text { for fixed installation at guests` rooms } \\
\text { and back areas at the hotel and public } \\
\text { areas. }\end{array}$ & $0(0)$ & $2(7.7)$ & $0(0)$ & $\begin{array}{c}15 \\
(57.7)\end{array}$ & 9 (34.6) & 4.24 & 0.86 \\
\hline $\begin{array}{l}19 . \text { Raising the hotel`s personnel } \\
\text { awareness of water conservation. }\end{array}$ & $0(0)$ & $0(0)$ & $0(0)$ & $\begin{array}{c}11 \\
(42.3)\end{array}$ & $15(57.7)$ & 4.48 & 0.79 \\
\hline $\begin{array}{l}Y \cdot \text { Stick guiding posters to remind } \\
\text { the guests of how to reduce water }\end{array}$ & $2(7.7)$ & $1(3.8)$ & $1(3.8)$ & 9 (34.6) & $13(50)$ & 5.30 & 7.23 \\
\hline
\end{tabular}




\begin{tabular}{|c|c|c|c|c|c|c|c|}
\hline \multirow{2}{*}{ Items } & Never & Seldom & Sometimes & Often & Always & \multirow{2}{*}{ Mean } & \multirow{2}{*}{ S.D } \\
\hline & No. $(\%)$ & No. $(\%)$ & No. $(\%)$ & No. $(\%)$ & No. $(\%)$ & & \\
\hline \multicolumn{8}{|l|}{ consumption. } \\
\hline $\begin{array}{l}\text { 21. Keep reports on the location and } \\
\text { the type of Water leakage in central } \\
\text { areas. }\end{array}$ & $0(0 \%)$ & $\begin{array}{c}1 \\
(3.8 \%)\end{array}$ & $0(0 \%)$ & $9(34.6)$ & $\begin{array}{c}16 \\
(61.5)\end{array}$ & 4.57 & 0.66 \\
\hline $\begin{array}{l}\text { 22. Water leakage fixing ware and } \\
\text { spares are put near the leakage areas } \\
\text { to make sure that treatment is made } \\
\text { in a short time. }\end{array}$ & $0(0)$ & $0(0)$ & $0(0)$ & $5(19.2)$ & $\begin{array}{c}21 \\
(80.8)\end{array}$ & 4.81 & 0.39 \\
\hline $\begin{array}{l}\text { 23. The maintenance team are } \\
\text { motivated to discover any leakage in } \\
\text { water network. }\end{array}$ & $0(0)$ & $0(0)$ & $0(0)$ & $6(23.1)$ & $\begin{array}{c}20 \\
(76.9)\end{array}$ & 4.75 & 0.50 \\
\hline $\begin{array}{l}\text { 24. Providing the maintenance team } \\
\text { with the necessary tools and wares } \\
\text { and urging them to prioritize fixing } \\
\text { water leakage. }\end{array}$ & $0(0)$ & $0(0)$ & $0(0)$ & $8(30.8)$ & $\begin{array}{c}18 \\
(69.2)\end{array}$ & 4.60 & 0.65 \\
\hline $\begin{array}{l}\text { 25. Using reverse water flow wares } \\
\text { to prevent pollution resulted from } \\
\text { sewage and other sources of } \\
\text { pollution. }\end{array}$ & $1(3.8)$ & $1(3.8)$ & $0(0)$ & $9(34.6)$ & $\begin{array}{c}15 \\
(57.7)\end{array}$ & 4.42 & 1.00 \\
\hline $\begin{array}{l}\text { 26. Inspecting fire extinguisher } \\
\text { regularly to make sure that water } \\
\text { flow just occurs in case of fire. }\end{array}$ & $0(0)$ & $0(0)$ & $0(0)$ & $7(26.9)$ & $\begin{array}{c}19 \\
(73.1)\end{array}$ & 4.69 & 0.52 \\
\hline
\end{tabular}

Table 4 illustrated that higher percentage of hotel managers mentioned that they always try to rational water consumption in guests' room, in form of detection of leakage, using low flow shower, and using of time control system, heat control, automatic water and shower shut off, low pressure dual, flow control valve, awareness poster to guests, and recycling water in bathrooms. On the other hand, they mentioned that they often use remote control shut off value and often to install aerating faucets.

Guestrooms, laundries, and kitchens are the major water users in a hotel. An example given at the World Travel Market in London in November 2008 by Hilton Hotels showed that average water usage figures were: $33-35 \%$ in the guestroom, $15-25 \%$ in food and beverage preparation, $5-17 \%$ in laundry, $2-16 \%$ in air conditioning and 2-15\% in the garden and pool (Bohdanowicz and Martinac, 2007). Water consumption depends not only on the type, standard and range of a facility, but also on the services provided and on existing water conservation practices (Erdogan and Baris, 2007).

Deng and Burnett (2000) said that in most of hotels and accommodation services, the majority of water is used in guest rooms which typically consume between 40 to $56 \%$ of the total water consumption of a hotel. The occupancy levels vary significantly from time to time over a year and more water is consumed when there are more guests in the hotel. (March et al., 2004) added that water consumption of a hotel varies widely with changes in occupancy because of the high water base load consumed by the staff in support operations. Further, Charara et al. (2011) added that the owners of the hotel are responsible for the employees, working in it, they can educate the employees about water conservation and to use water more efficiently in water consumptive activities (Tang, 2012). 
International Journal of Heritage, Tourism and Hospitality Vol. (14), No. (1), June, 2020

Table 4: Frequency of different response about Measures taken to rationalize water consumption in rooms

\begin{tabular}{|c|c|c|c|c|c|c|c|}
\hline \multirow{2}{*}{ Items } & Never & Seldom & Sometimes & Often & Always & \multirow{2}{*}{ Mean } & \multirow{2}{*}{ S.D } \\
\hline & No. (\%) & No. $(\%)$ & No. $(\%)$ & No. (\%) & No. $(\%)$ & & \\
\hline $\begin{array}{l}\text { 1. Detecting water leakage in } \\
\text { rooms. }\end{array}$ & $0(0)$ & $0(0)$ & $0(0)$ & $4(15.4)$ & $\begin{array}{c}22 \\
(84.6)\end{array}$ & 4.87 & 0.33 \\
\hline $\begin{array}{l}\text { 2. Using low flow and regulated } \\
\text { flow shower heads. }\end{array}$ & $0(0)$ & $0(0)$ & $0(0)$ & $7(26.9)$ & $\begin{array}{c}19 \\
(73.1)\end{array}$ & 4.75 & 0.43 \\
\hline $\begin{array}{l}\text { 3. Using remote or time control } \\
\text { systems to control faucets and } \\
\text { shower heads. }\end{array}$ & $0(0)$ & $2(7.7)$ & $0(0)$ & $6(23.1)$ & $\begin{array}{c}18 \\
(69.2)\end{array}$ & 4.45 & 1.00 \\
\hline 4. Using heat control shower heads. & $0(0)$ & $1(3.8)$ & $0(0)$ & $9(34.6)$ & $\begin{array}{c}16 \\
(61.5)\end{array}$ & 4.51 & 0.79 \\
\hline $\begin{array}{l}\text { 5. Using automatic water shut off } \\
\text { showers. }\end{array}$ & $0(0)$ & $6(23.1)$ & $0(0)$ & $4(15.4)$ & $\begin{array}{c}16 \\
(61.5)\end{array}$ & 4.18 & 1.28 \\
\hline $\begin{array}{l}\text { 6. Using Automatic water shut off } \\
\text { faucets. }\end{array}$ & $0(0)$ & $6(23.1)$ & $0(0)$ & $7(26.9)$ & $13(50)$ & 3.96 & 1.28 \\
\hline $\begin{array}{l}\text { 7. Using remote control shut off } \\
\text { valve. }\end{array}$ & $0(0)$ & $12(46.2)$ & $0(0)$ & $5(19.2)$ & $9(34.6)$ & 3.36 & 1.45 \\
\hline 8. Installing aerating faucets. & $2(7.7)$ & $11(42.3)$ & $0(0)$ & $5(19.2)$ & $8(30.8)$ & 3.40 & 1.52 \\
\hline $\begin{array}{l}\text { 9. Dual low pressure flushes in } \\
\text { bathrooms. }\end{array}$ & $1(3.8)$ & $9(34.6)$ & $1(3.8)$ & $4(15.4)$ & $\begin{array}{c}11 \\
(42.3)\end{array}$ & 3.60 & 1.51 \\
\hline 10. Using water flow control valves. & $0(0)$ & $3(11.5)$ & $0(0)$ & $9(34.6)$ & $\begin{array}{c}14 \\
(53.8)\end{array}$ & 4.39 & 0.89 \\
\hline $\begin{array}{l}\text { 11. Sticking guiding posters to } \\
\text { encourage guests reduce water } \\
\text { consumption. }\end{array}$ & $0(0)$ & $1(3.8)$ & $0(0)$ & $6(23.1)$ & $\begin{array}{c}19 \\
(73.1)\end{array}$ & 4.48 & 1.00 \\
\hline $\begin{array}{l}\text { 12. Recycling water used in } \\
\text { bathrooms. }\end{array}$ & $0(0)$ & $2(7.7)$ & $0(0)$ & $5(19.2)$ & $\begin{array}{c}19 \\
(73.1)\end{array}$ & 4.45 & 1.00 \\
\hline
\end{tabular}

Table (5) illustrates that higher percentage of hotel managers mentioned that they always use some procedures to do internal supervision of water use in form of putting a plan for towel and bed sheets reuse, use time remote foe faucets and showers, use automatic shower, and faucets shut off, also use remote control shut off and flow control valve, in addition they mentioned that they always use low pressure flush, and install aerating faucets, as regards washing towels they did when guests demand, they always stick guiding posters in toilets, and they replace insufficient toilet with dual system of water flush.

On the other hand they said they often train personnel on efficient cleaning technique, and they often to detect or reporting leakage, stick guiding posters, or recycling water in bathroom.

Table 5: Frequency of different response about water usage internal supervision

\begin{tabular}{|l|c|c|c|c|c|c|c|}
\hline \multicolumn{1}{|c|}{ Items } & Never & Seldom & Sometimes & Often & Always & Mean & S.D. \\
\cline { 2 - 7 } & No. (\%) & No. (\%) & No. (\%) & No. (\%) & No. (\%) & & \\
\hline $\begin{array}{l}\text { 1. Plans for reusing towels and } \\
\text { bed sheets to reduce the quantity } \\
\text { of washing. }\end{array}$ & $0(0)$ & $0(0)$ & $0(0)$ & $4(15.4)$ & $22(84.6)$ & 4.84 & 0.36 \\
\hline $\begin{array}{l}\text { 2. Training personnel on the } \\
\text { efficient cleaning techniques to } \\
\text { reduce the consumption use of } \\
\text { water and chemical stuffs. }\end{array}$ & $0(0)$ & $0(0)$ & $0(0)$ & $14(53.8)$ & $12(46.2)$ & 4.50 & 0.50 \\
\hline $\begin{array}{l}\text { 3. Using remote or time control } \\
\text { systems to control faucets and }\end{array}$ & $0(0)$ & $1(3.8)$ & $1(3.8)$ & $11(42.3)$ & $13(50)$ & 4.31 & 0.93 \\
\hline
\end{tabular}




\begin{tabular}{|c|c|c|c|c|c|c|c|}
\hline \multirow{2}{*}{ Items } & Never & Seldom & Sometimes & Often & Always & \multirow{2}{*}{ Mean } & \multirow{2}{*}{ S.D. } \\
\hline & No. $(\%)$ & No. $(\%)$ & No. $(\%)$ & No. $(\%)$ & No. $(\%)$ & & \\
\hline \multicolumn{8}{|l|}{ shower heads. } \\
\hline $\begin{array}{l}\text { 4. Detecting and reporting if there } \\
\text { is water leakage. }\end{array}$ & $0(0)$ & $0(0)$ & $0(0)$ & $14(53.8)$ & $12(46.2)$ & 4.54 & 0.50 \\
\hline $\begin{array}{l}\text { 5. Using Automatic water shut off } \\
\text { showers. }\end{array}$ & $0(0)$ & $3(11.5)$ & $0(0)$ & $11(42.3)$ & $12(46.2)$ & 4.18 & 1.13 \\
\hline $\begin{array}{l}\text { 6. Using automatic water shut off } \\
\text { faucets. }\end{array}$ & $0(0)$ & $1(3.8)$ & $0(0)$ & $9(34.6)$ & $16(61.5)$ & 4.51 & 0.90 \\
\hline $\begin{array}{l}\text { 7. Using remote control shut off } \\
\text { valve. }\end{array}$ & $1(3.8)$ & $3(11.5)$ & $0(0)$ & $6(23.1)$ & $16(61.5)$ & 4.30 & 1.23 \\
\hline 8. Installing aerating faucets. & $3(11.5)$ & $0(0)$ & $0(0)$ & $7(26.9)$ & $16(61.5)$ & 4.36 & 1.16 \\
\hline $\begin{array}{l}\text { 9. Dual low pressure flushes in } \\
\text { bathrooms. }\end{array}$ & $0(0)$ & $0(0)$ & $1(3.8)$ & $11(42.3)$ & $14(53.8)$ & 4.48 & 0.71 \\
\hline $\begin{array}{l}\text { 10. Using water flow control } \\
\text { valves. }\end{array}$ & $0(0)$ & $0(0)$ & $0(0)$ & $10(38.5)$ & $16(61.5)$ & 4.63 & 0.48 \\
\hline $\begin{array}{l}\text { 11. Sticking guiding posters to } \\
\text { encourage guests reduce water } \\
\text { consumption. }\end{array}$ & $0(0)$ & $0(0)$ & $0(0)$ & $15(57.7)$ & $11(42.3)$ & 4.33 & 0.77 \\
\hline $\begin{array}{l}\text { 12. Recycling water used in } \\
\text { bathrooms. }\end{array}$ & $0(0)$ & $1(3.8)$ & $0(0)$ & $13(50)$ & $12(46.2)$ & 4.42 & 0.66 \\
\hline $\begin{array}{l}\text { 13. Washing towels and bed } \\
\text { sheets only if guests demand. }\end{array}$ & $0(0)$ & $0(0)$ & $0(0)$ & 9 (34.6) & $17(65.4)$ & 4.66 & 0.47 \\
\hline $\begin{array}{l}\text { 14. Sticking guiding posters in all } \\
\text { toilets to inform guests of the } \\
\text { required quantity of water to wash } \\
\text { towels and bed sheets. }\end{array}$ & $0(0)$ & $0(0)$ & $0(0)$ & $11(42.3)$ & $15(57.7)$ & 4.48 & 0.79 \\
\hline $\begin{array}{l}\text { 15. Replacing inefficient toilets } \\
\text { with others containing dual } \\
\text { systems of water flush. }\end{array}$ & $1(3.8)$ & $1(3.8)$ & $0(0)$ & $11(42.3)$ & $13(50)$ & 4.06 & 1.32 \\
\hline
\end{tabular}

Table 6 illustrates that higher percentage of hotel managers mentioned that they always store rinsing water and offer reuse program, using fast rotation washing machines, with correct amount of soap, and running washing machine only when fully loaded, mangers also mention that they categorize laundry according to level of dirt, and they installed program for small load, but with high load they use tunnel washing machine, they also tried to provide worker the efferent practice, and used high slandered in laundry, and used dry machine of impurities collecting systems.

Hotels generate a considerable amount of laundry, comprising bed sheets, pillowcases, duvet covers, towels, tablecloths and napkins, and staff uniforms (Deng and Burnett, 2000). The amount of water used in laundry operations can account for up to $20 \%$ of the total volume of water consumed by a hotel and is mainly influenced by the type of equipment available and the level of training of the laundry employees (Charara et al., 2011). Hence, home laundry load has been widely accepted as a major influential factor of water consumption in a hotel facility by a number of researchers (Tang, 2012).

Table 6: Frequency of different response about water usage in laundry

\begin{tabular}{|c|c|c|c|c|c|c|c|}
\hline \multirow{2}{*}{ Items } & Never & Seldom & Sometimes & Often & Always & \multirow{2}{*}{ Mean } & \multirow{2}{*}{ S.D. } \\
\hline & No. $(\%)$ & No. (\%) & No. (\%) & No. (\%) & No. (\%) & & \\
\hline $\begin{array}{l}\text { 1. Storing rinsing water in tanks } \\
\text { and Offering reuse programs. }\end{array}$ & $0(0)$ & $0(0)$ & $0(0)$ & $10(38.5)$ & $16(61.5)$ & 4.69 & 0.46 \\
\hline
\end{tabular}




\begin{tabular}{|l|c|c|c|c|c|c|c|}
\hline \multicolumn{1}{|c|}{ Items } & Never & Seldom & Sometimes & Often & Always & Mean & S.D. \\
\cline { 2 - 6 } & No. (\%) & No. (\%) & No. (\%) & No. (\%) & No. (\%) & & \\
\hline $\begin{array}{l}\text { 2. Using Fast rotation washing } \\
\text { machines to reduce the amount of } \\
\text { water required for washing before } \\
\text { the process of drying. }\end{array}$ & $0(0)$ & $0(0)$ & $0(0)$ & $9(34.6)$ & $17(65.4)$ & 4.72 & 0.45 \\
\hline $\begin{array}{l}\text { 3. Using the correct amount of } \\
\text { soap to load size so extra rinsing } \\
\text { is not required. }\end{array}$ & $1(3.8)$ & $0(0)$ & $0(0)$ & $10(38.5)$ & $15(57.7)$ & 4.60 & 0.65 \\
\hline $\begin{array}{l}\text { 4. Running the washing machine } \\
\text { only with a full load Minimize } \\
\text { rinse cycles as much as possible } \\
\text { without reducing quality to save } \\
\text { water. }\end{array}$ & $0(0)$ & $0(0)$ & $0(0)$ & $9(34.6)$ & $17(65.4)$ & 4.69 & 0.46 \\
\hline $\begin{array}{l}\text { 5. Laundry is categorized } \\
\text { according to its level of dirt. }\end{array}$ & $0(0)$ & $0(0)$ & $0(0)$ & $10(38.5)$ & $16(61.5)$ & 4.63 & 0.48 \\
\hline $\begin{array}{l}\text { 6. Installing programs for small } \\
\text { load. }\end{array}$ & $0(0)$ & $0(0)$ & $0(0)$ & $9(34.6)$ & $17(65.4)$ & 4.75 & 0.43 \\
\hline $\begin{array}{l}\text { 7. Using tunnel washing machines } \\
\text { to wash large quantity of laundry. }\end{array}$ & $0(0)$ & $0(0)$ & $0(0)$ & $9(34.6)$ & $17(65.4)$ & 4.69 & 0.46 \\
\hline $\begin{array}{l}\text { 8. Providing laundry workers } \\
\text { efficient practices to use efficient } \\
\text { technical cleaning. }\end{array}$ & $0(0)$ & $0(0)$ & $0(0)$ & $8(30.8)$ & $18(69.2)$ & 4.72 & 0.45 \\
\hline $\begin{array}{l}\text { 9. Using laundry equipment of } \\
\text { highly specification and criteria } \\
\text { standard. }\end{array}$ & $0(0)$ & $0(0)$ & $0(0)$ & $9(34.6)$ & $17(65.4)$ & 4.69 & 0.46 \\
\hline $\begin{array}{l}\text { 10. Using dry machines of } \\
\text { impurities collecting systems. }\end{array}$ & $0(0)$ & $0(0)$ & $0(0)$ & $8(30.8)$ & $18(69.2)$ & 4.75 & 0.43 \\
\hline
\end{tabular}

Table 7 illustrates that all hotel managers mentioned that in kitchen they always use equipment's that depend on air cooled condensers, dry steam heater, also they used dish washer only when fully loaded, and close its door tightly to prevent loss of steam.

They also use equipment with high technology (as fridge, freezer and washing machine) based on water and power saving standards, with low pressure valve, and effective programs, with proper training of kitchen staff on high technology of cleaning and cooking.

A hotel building provides a variety of facilities and functions. In addition to the preparation of food for home guests, kitchen staff has to make food covers for restaurants in hotels which are open to both in-house guests and the general public (Bohdanowicz and Martinac, 2007). Water consumption in kitchens may also depend on the type of equipment used to organize those food covers (Tang, 2012).

Table 7: Frequency of different response about water usage in kitchen

\begin{tabular}{|l|l|l|l|l|l|l|l|}
\hline \multicolumn{1}{|c|}{ Items } & Never & Seldom & Sometimes & Often & Always & Mean & S.D. \\
\cline { 2 - 6 } & No. (\%) & No. (\%) & No. (\%) & No. (\%) & No. (\%) & & \\
\hline $\begin{array}{l}\text { Using equipment that depends on } \\
\text { air-cooled condensers rather than } \\
\text { water to cool their condensers. }\end{array}$ & $0(0)$ & $0(0)$ & $0(0)$ & $0(0)$ & $26(100)$ & 5.00 & 0.00 \\
\hline $\begin{array}{l}\text { Using dry steam heaters that do } \\
\text { not use water to keep food hot. }\end{array}$ & $0(0)$ & $0(0)$ & $0(0)$ & $0(0)$ & $26(100)$ & 5.00 & 0.00 \\
\hline $\begin{array}{l}\text { Using dishwasher only when it is } \\
\text { full load. }\end{array}$ & $0(0)$ & $0(0)$ & $0(0)$ & $0(0)$ & $26(100)$ & 5.00 & 0.00 \\
\hline
\end{tabular}




\begin{tabular}{|l|c|c|c|c|c|c|c|}
\hline \multicolumn{1}{|c|}{ Items } & Never & Seldom & Sometimes & Often & Always & Mean & S.D. \\
\cline { 2 - 6 } & No. (\%) & No. (\%) & No. (\%) & No. (\%) & No. (\%) & & \\
\hline $\begin{array}{l}\text { Closing dishwashers doors } \\
\text { tightly to prevent loss of steam. }\end{array}$ & $0(0)$ & $0(0)$ & $0(0)$ & $0(0)$ & $26(100)$ & 5.00 & 0.00 \\
\hline $\begin{array}{l}\text { Using equipments that comply } \\
\text { with local standards according to } \\
\text { energy and water efficiency } \\
\text { programs to save water and } \\
\text { energy. }\end{array}$ & $0(0 \%)$ & $0(0 \%)$ & $0(0 \%)$ & $0(0 \%)$ & $26(100)$ & 5.00 & 0.00 \\
\hline $\begin{array}{l}\text { Using high technological } \\
\text { equipment (fridges, freezers, } \\
\text { washing machines) to reduce } \\
\text { water consumption. }\end{array}$ & $0(0)$ & $0(0)$ & $0(0)$ & $0(0)$ & $26(100)$ & 5.00 & 0.00 \\
\hline $\begin{array}{l}\text { Using low pressure valves to } \\
\text { wash dishes effectively and } \\
\text { reduce water consumption. }\end{array}$ & $0(0)$ & $0(0)$ & $0(0)$ & $0(0)$ & $26(100)$ & 5.00 & 0.00 \\
\hline $\begin{array}{l}\text { Using effective programmed } \\
\text { dishwashers to reuse water and } \\
\text { heat. }\end{array}$ & $0(0)$ & $0(0)$ & $0(0)$ & $0(0)$ & $26(100)$ & 5.00 & 0.00 \\
\hline $\begin{array}{l}\text { Training kitchen staff on using } \\
\text { effectively high technical cleaning } \\
\text { and cooking. }\end{array}$ & $0(0)$ & $0(0)$ & $0(0)$ & $0(0)$ & $26(100)$ & 5.00 & 0.00 \\
\hline
\end{tabular}

\section{External use of water}

a. Swimming pools.

b. Irrigating gardens and planted areas.

Tang (2012) said that a hotel building provides a variety of facilities and functions and is normally operated 24 hours a day throughout the year. According to Meade and Gonzalez-Morel (2011), the composition of a hotel's water consumption can be presented as $34 \%$ guest rooms, $22 \%$ kitchen, 20\% public bathrooms, 17\% laundry, $1 \%$ Heating, Ventilating and Air Conditioning, $4 \%$ steam generation and $2 \%$ for swimming pool in Germany.

Table (8) illustrated that higher percentage of hotel managers mentioned that they often to reduce pool size or area, covering up the pool, and improve the efficiency of backwash when cleaning filters, finally they maintain a lower pool temperature and a proper chemical balance. But they always use trees and fences as water flow barriers, keep a lower water level in the pool, design sliding borders surrounding the swimming pools, install appropriate filtration system, recycle water used in cleaning filters in irrigation, and they Install appropriate filtration system.

Table 8: Frequency of different response about water usage in swimming pools

\begin{tabular}{|l|c|c|c|c|c|c|c|}
\hline \multicolumn{1}{|c|}{ Items } & Never & \multicolumn{1}{c|}{ Seldom } & Sometimes & Often & Always & Mean & S.D. \\
\cline { 2 - 6 } & No. (\%) & No. (\%) & No. (\%) & No. (\%) & No. (\%) & \\
\hline $\begin{array}{l}\text { 1. Reducing the sizes and the } \\
\text { areas of swimming pools. }\end{array}$ & $1(3.8)$ & $1(3.8)$ & $1(3.8)$ & $14(53.8)$ & $9(34.6)$ & 3.96 & 1.03 \\
\hline $\begin{array}{l}\text { 2. Covering up the pools when } \\
\text { they are not in service to } \\
\text { minimize evaporation. }\end{array}$ & $3(11.5)$ & $0(0)$ & $0(0)$ & $15(57.7)$ & $8(30.8)$ & 3.87 & 1.33 \\
\hline $\begin{array}{l}\text { 3. Improving the efficiency of } \\
\text { backwashing process when } \\
\text { cleaning filters. }\end{array}$ & $0(0)$ & $0(0)$ & $0(0)$ & $13(50)$ & $13(50)$ & 4.56 & 0.50 \\
\hline $\begin{array}{l}\text { 4. Maintaining a lower pool } \\
\text { temperature and a proper }\end{array}$ & $0(0)$ & $0(0)$ & $0(0)$ & $14(53.8)$ & $12(46.2)$ & 4.56 & 0.50 \\
\hline
\end{tabular}




\begin{tabular}{|c|c|c|c|c|c|c|c|}
\hline \multirow{2}{*}{ Items } & Never & Seldom & Sometimes & Often & Always & \multirow{2}{*}{ Mean } & \multirow{2}{*}{ S.D. } \\
\hline & No. (\%) & No. (\%) & No. (\%) & No. (\%) & No. (\%) & & \\
\hline $\begin{array}{l}\text { chemical balance to avoid the } \\
\text { need to drain the pool and to } \\
\text { reduce evaporation, particularly } \\
\text { when not in use. }\end{array}$ & & & & & & & \\
\hline $\begin{array}{l}\text { 5. Using trees and fences as water } \\
\text { flow barriers to reduce water loss } \\
\text { from wind evaporation. }\end{array}$ & $1(3.8)$ & $1(3.8)$ & $0(0)$ & $1(38.5)$ & $14(53.8)$ & 4.21 & 1.21 \\
\hline $\begin{array}{l}\text { 6. Keeping a lower water level in } \\
\text { the pool to reduce water loss from } \\
\text { extreme splashing and boisterous } \\
\text { water play. }\end{array}$ & $0(0)$ & $0(0)$ & $0(0)$ & $12(46.2)$ & $14(53.8)$ & 4.63 & 0.48 \\
\hline $\begin{array}{l}\text { 7. Designing sliding borders } \\
\text { surrounding the swimming pools } \\
\text { to gather wastewater to be } \\
\text { recycled afterwards. }\end{array}$ & $0(0)$ & $0(0)$ & $0(0)$ & $4(15.4)$ & $22(84.6)$ & 4.87 & 0.33 \\
\hline $\begin{array}{l}\text { 8. Installing appropriate filtration } \\
\text { system to reduce water } \\
\text { consumption. }\end{array}$ & $0(0)$ & $0(0)$ & $0(0)$ & $5(19.2)$ & $21(80.8)$ & 4.84 & 0.36 \\
\hline $\begin{array}{l}\text { 9. Recycling water used in } \\
\text { cleaning filters in irrigation. }\end{array}$ & $0(0)$ & $0(0)$ & $0(0)$ & $5(19.2)$ & $21(80.8)$ & 4.75 & 0.61 \\
\hline $\begin{array}{l}\text { 10. Installing appropriate } \\
\text { filtration system to reduce } \\
\text { reducing the process of draining } \\
\text { the pool. }\end{array}$ & $0(0)$ & $0(0)$ & $0(0)$ & $5(19.2)$ & $21(80.8)$ & 4.84 & 0.36 \\
\hline
\end{tabular}

Table (9) illustrated that higher percentage of hotel managers mentioned that they always design garden appropriately with appropriate distribution of plant area, also they did allocation of water to area seen by guests, select soil that hold water, and improve soil by organic fertilization, plant tress that need less water, collect plants need same water requirement, decrease grass area, use drip irrigation, and irrigate in suitable time with slandered schedule, and recycle water in irrigation, they follow all these procedure to conserve water in garden area.

Table 9: Frequency of different response about water usage in irrigating gardens and planted areas

\begin{tabular}{|l|c|c|c|c|c|c|c|}
\hline \multicolumn{1}{|c}{ Items } & Never & Seldom & Sometimes & Often & Always & Mean & S.D. \\
\cline { 2 - 6 } & No. (\%) & No. (\%) & No. (\%) & No. (\%) & No. (\%) & & \\
\hline $\begin{array}{l}\text { 1. Designing gardens appropriately } \\
\text { in a way that reduces water } \\
\text { consumption. }\end{array}$ & $1(3.8)$ & $0(0)$ & $0(0)$ & $7(26.9)$ & $18(69.2)$ & 4.63 & 0.78 \\
\hline $\begin{array}{l}\text { 2. Appropriate distribution of } \\
\text { planted areas according to the } \\
\text { amount of water required for } \\
\text { irrigation. }\end{array}$ & $0(0)$ & $0(0)$ & $0(0)$ & $11(42.3)$ & $15(57.7)$ & 4.60 & 0.49 \\
\hline $\begin{array}{l}\text { 3. Allocating larger amount of } \\
\text { water to areas that are seen by } \\
\text { guests. }\end{array}$ & $0(0)$ & $0(0)$ & $0(0)$ & $8(30.8)$ & $18(69.2)$ & 4.72 & 0.45 \\
\hline $\begin{array}{l}\text { 4. Select soil with high water } \\
\text { holding capacity for landscaping } \\
\text { works to reduce infiltration loss. }\end{array}$ & $0(0)$ & $0(0)$ & $0(0)$ & $11(42.3)$ & $15(57.7)$ & 4.63 & 0.48 \\
\hline $\begin{array}{l}\text { 5. Using Compost or decomposed } \\
\text { organic matter as fertilizer to }\end{array}$ & $0(0)$ & $0(0)$ & $0(0)$ & $10(38.5)$ & $16(61.5)$ & 4.63 & 0.48 \\
\hline
\end{tabular}




\begin{tabular}{|c|c|c|c|c|c|c|c|}
\hline \multirow{2}{*}{ Items } & Never & Seldom & Sometimes & Often & Always & \multirow{2}{*}{ Mean } & \multirow{2}{*}{ S.D. } \\
\hline & No. $(\%)$ & No. $(\%)$ & No. $(\%)$ & No. $(\%)$ & No. $(\%)$ & & \\
\hline \multicolumn{8}{|l|}{$\begin{array}{l}\text { improve soil structure and } \\
\text { increasing its water holding } \\
\text { capacity. }\end{array}$} \\
\hline $\begin{array}{l}\text { 6. Select plants that require little or } \\
\text { no watering. }\end{array}$ & $0(0)$ & $0(0)$ & $0(0)$ & 7 (26.9) & $19(73.1)$ & 4.65 & 0.65 \\
\hline $\begin{array}{l}\text { 7. Planting trees and bushes that } \\
\text { require less water. }\end{array}$ & $0(0)$ & $0(0)$ & $0(0)$ & $11(42.3)$ & $15(57.7)$ & 4.56 & 0.50 \\
\hline $\begin{array}{l}\text { 8. Plants with similar water } \\
\text { requirement should be grouped } \\
\text { and planted together. }\end{array}$ & $0(0)$ & $1(3.8)$ & $0(0)$ & $11(42.3)$ & $14(53.8)$ & 4.53 & 0.67 \\
\hline $\begin{array}{l}\text { 9. Covering the ground with plants } \\
\text { and bushes. }\end{array}$ & $0(0)$ & $0(0)$ & $0(0)$ & $11(42.3)$ & $14(53.8)$ & 4.61 & 0.49 \\
\hline $\begin{array}{l}\text { 10. Reducing grass areas to save } \\
\text { water. }\end{array}$ & $0(0)$ & $0(0)$ & $0(0)$ & $12(46.2)$ & $14(53.8)$ & 4.57 & 0.50 \\
\hline $\begin{array}{l}\text { 11. Depending on highly efficient } \\
\text { Drip irrigation systems. }\end{array}$ & $0(0)$ & $0(0)$ & $0(0)$ & $6(23.1)$ & $20(76.9)$ & 4.81 & 0.39 \\
\hline $\begin{array}{l}\text { 12. Using sprinkler irrigation } \\
\text { system to reduce water } \\
\text { consumption. }\end{array}$ & $0(0)$ & $0(0)$ & $0(0)$ & 9 (34.6) & $17(65.4)$ & 4.66 & 0.47 \\
\hline 13. Not using hoses in irrigation. & $1(3.8)$ & $0(0)$ & $0(0)$ & $4(15.4)$ & $21(80.8)$ & 4.70 & 0.78 \\
\hline $\begin{array}{l}\text { 14. Watering in the morning or } \\
\text { evening instead of in the middle of } \\
\text { the day to minimize water loss } \\
\text { through evaporation. }\end{array}$ & $0(0)$ & $0(0)$ & $0(0)$ & $8(30.8)$ & $18(69.2)$ & 4.71 & 0.45 \\
\hline $\begin{array}{l}\text { 15. Adapting irrigation schedule to } \\
\text { the region's climate. }\end{array}$ & $0(0)$ & $0(0)$ & $0(0)$ & $6(23.1)$ & $20(76.9)$ & 4.65 & 0.78 \\
\hline $\begin{array}{l}\text { 16. Using gradation and inclination } \\
\text { rule to direct the flow of the } \\
\text { surface water and storm sewer to } \\
\text { the gardens and the planted areas. }\end{array}$ & $0(0)$ & $0(0)$ & $0(0)$ & $10(38.5)$ & $16(61.5)$ & 4.56 & 0.80 \\
\hline $\begin{array}{l}\text { 17. Reusing of properly treated } \\
\text { wastewater or desalination of } \\
\text { brackish water in irrigating } \\
\text { gardens and other planted areas. }\end{array}$ & $0(0)$ & $0(0)$ & $0(0)$ & $13(50)$ & $13(50)$ & 4.40 & 0.79 \\
\hline $\begin{array}{l}\text { 18. Putting sawdust (either organic } \\
\text { or nonorganic) on the plants `stem } \\
\text { s to keep the soil moisture and to } \\
\text { prevent unwanted water } \\
\text { consuming plants from growing. }\end{array}$ & $1(3.8)$ & $0(0)$ & $1(3.8)$ & $12(46.2)$ & $12(46.2)$ & 4.28 & 1.02 \\
\hline $\begin{array}{l}\text { 19. Inspect irrigation equipment } \\
\text { regularly and repair any defects or } \\
\text { leakage promptly. }\end{array}$ & $0(0)$ & $0(0)$ & $0(0)$ & $11(42.3)$ & $15(57.7)$ & 4.59 & 0.49 \\
\hline $\begin{array}{l}\text { 20. Pruning and removing wanted } \\
\text { grasses to keep the efficiency of } \\
\text { the planted areas and achieve the } \\
\text { required level of water } \\
\text { conservation. }\end{array}$ & $0(0)$ & $0(0)$ & $0(0)$ & $11(42.3)$ & $15(57.7)$ & 4.63 & 0.48 \\
\hline
\end{tabular}

Table 10 and fig. 4 indicate that higher percentage of hotel managers more than three quarter of them mentioned that they believe in the absence of a culture of awareness of the importance of 
rationalizing water consumption, of them made an initiative to rationalize water consumption in their hotels, and inform all staff about water conservation, they also do continues water conservation supervision, with systematic measures were taken regular, by specific administration, and majority of them encountered difficulties and challenges to implement the policy of water conservation.

Table 10: Frequency of different response about water usage awareness

\begin{tabular}{|c|c|c|}
\hline \multirow{2}{*}{ Items } & No & Yes \\
\hline & No. $(\%)$ & No. $(\%)$ \\
\hline $\begin{array}{l}\text { 1. Do you believe in the absence of a culture of awareness of the importance } \\
\text { of rationalizing water consumption in the hotel sector? }\end{array}$ & $3(11.5 \%)$ & $23(88.5 \%)$ \\
\hline 2. Have you made an initiative to rationalize water consumption? & $7(26.9 \%)$ & $19(73.1 \%)$ \\
\hline 3. Did you inform all staff about water conservation? & $4(15.4 \%)$ & $22(84.6 \%)$ \\
\hline $\begin{array}{l}\text { 4. Is there continuous supervision of the staff of the hotel to rationalize water } \\
\text { consumption? }\end{array}$ & $4(15.4 \%)$ & $22(84.6 \%)$ \\
\hline $\begin{array}{l}\text { 5. Have systematic measures been taken to take full advantage of the water } \\
\text { used, treat and reuse it in areas other than human consumption? }\end{array}$ & $2(7.7 \%)$ & $24(92.3 \%)$ \\
\hline $\begin{array}{l}\text { 6. Has a special administration been allocated to rationalize the water } \\
\text { consumption of the hotel? }\end{array}$ & $1(3.8 \%)$ & $25(96.2 \%)$ \\
\hline $\begin{array}{l}\text { 7. Have you encountered difficulties and challenges to implement the policy } \\
\text { of water conservation in the hotel? }\end{array}$ & $1(3.8 \%)$ & $25(96.2 \%)$ \\
\hline
\end{tabular}

Figure 4: Water conservation awareness

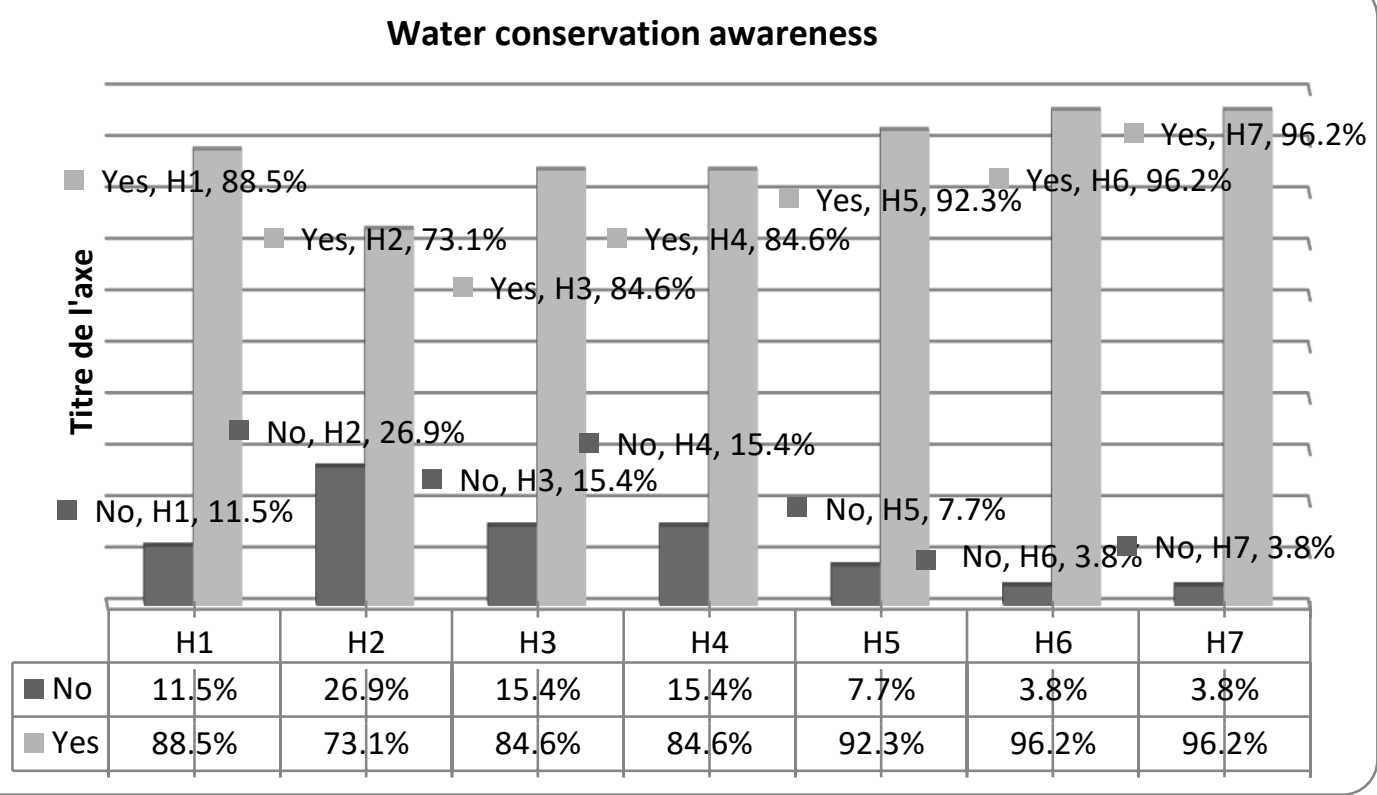

Table (11) and figs. ( $5 \& 6)$ illustrated that higher percentage of hotel managers mentioned that they raise water conservation awareness by educational seminars and training course and lower percentage mention that in periodic meetings.

As regards Difficulties and challenges facing implementation of water conversation policy more than three quarters mentioned lack of awareness, and conviction about water conservation, also lack of technicians who have sufficient skill and experience for maintenance, and lack of modern equipment and equipment at the hotel in addition to high cost of water conservation policy implementation.

Table 11: Frequency of different response about types of water conservation awareness and challenges 


\begin{tabular}{|c|c|c|}
\hline \multirow{2}{*}{ Items } & No & Yes \\
\hline & No. $(\%)$ & Yes. $(\%)$ \\
\hline \multicolumn{3}{|l|}{ Types of water conservation awareness } \\
\hline 1. Periodic meetings & $9(34.6 \%)$ & $17(65.4 \%)$ \\
\hline 2. Educational seminar & $5(19.2 \%)$ & $19(73.1 \%)$ \\
\hline 3. Training courses & $5(19.2 \%)$ & $19(73.1 \%)$ \\
\hline \multicolumn{3}{|c|}{ Difficulties and challenges facing implementation of water conservation policy } \\
\hline 1. Lack of awareness of the importance of rational consumption. & $2(7.7 \%)$ & $23(88.5 \%)$ \\
\hline 2. High cost. & $5(19.2 \%)$ & $19(73.1 \%)$ \\
\hline $\begin{array}{l}\text { 3. Lack of conviction about the importance of rationalization of } \\
\text { consumption. }\end{array}$ & $4(15.4 \%)$ & $20(76.9 \%)$ \\
\hline $\begin{array}{l}\text { 4. Lack of technicians who have sufficient skill and experience for } \\
\text { maintenance. }\end{array}$ & $6(23.1 \%)$ & $19(73.1 \%)$ \\
\hline 5. Lack of modern equipment and equipment at the hotel. & $4(15.4 \%)$ & $21(80.8 \%)$ \\
\hline
\end{tabular}

Figure (5): Types of water conservation awareness and challenges

Types of water conservation awareness and challenges

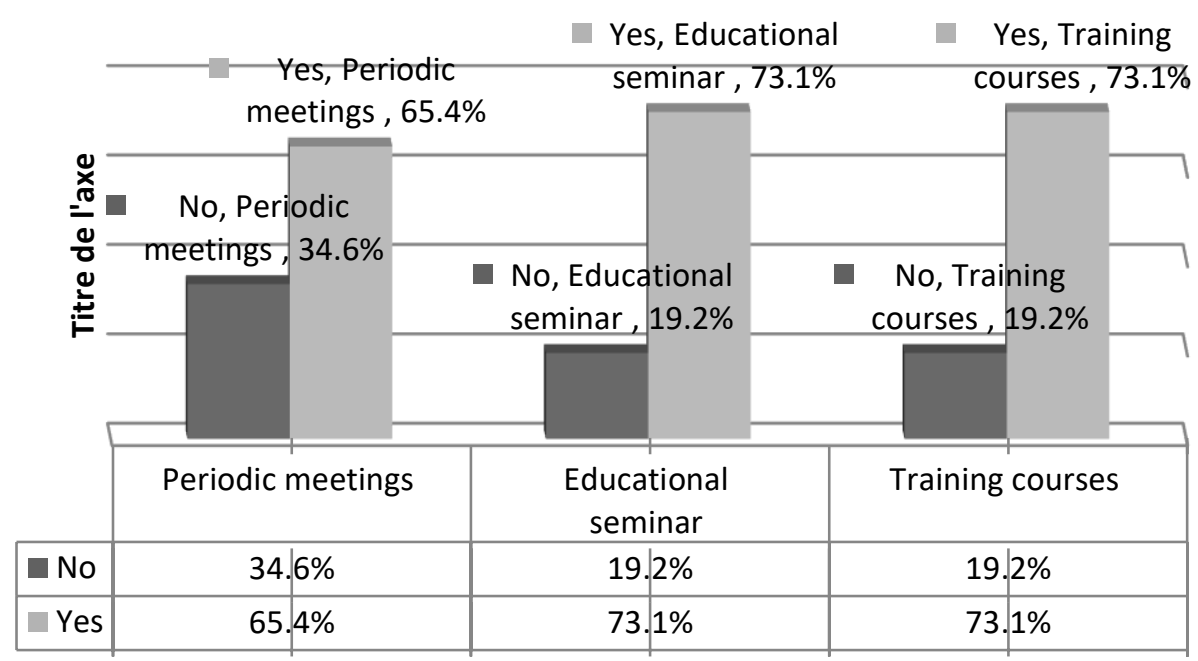


Figure 6: Types conservation awareness challenges

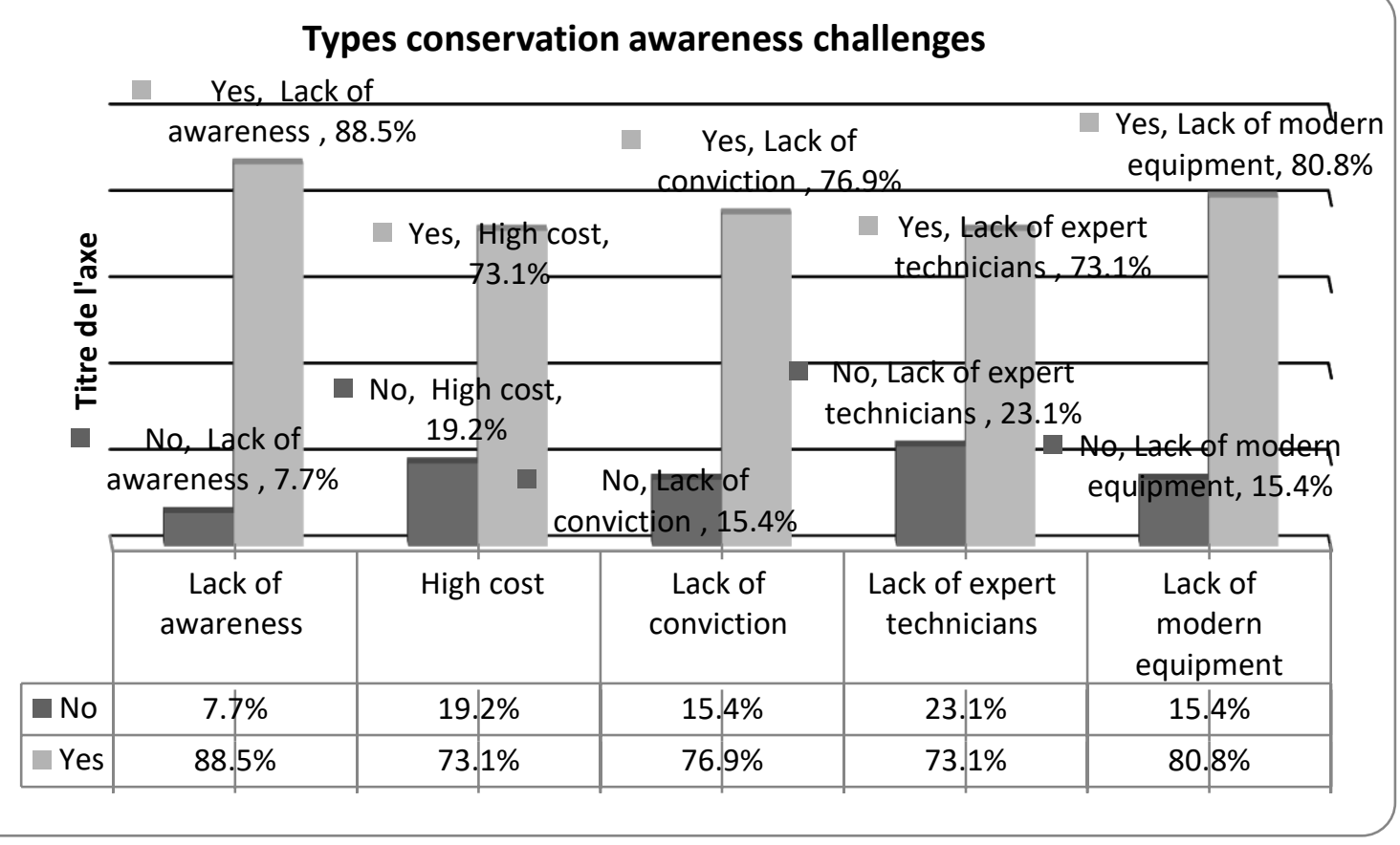

\section{Conclusion and implications for future research}

Freshwater is a strategic resource, necessary for sustaining life and achieving sustainable development. Hotel sector accounts for significant amount resource consumption as well as for a substantial part of the green impacts it generates. The operational nature of hotel industry itself requires a huge amount of water for its daily operations. A proper understanding on identified factors will enable the employees to address the water consumption factors effectively and to reduce the water consumption in hotel facilities in a significant level. This research investigated the relations between water consumption and organization in the hotel industry of Hurghada under a water crisis. We found that five stars' hotels in Hurghada city were likely to consume more water per establishment, had more complex consumption structures including a variety of water consuming services offered to guests. Water consumption depended not only on the type, standard and size of the facility, but also on the services offered and existing water conservation practices. Hence, since water scarcity elicits different responses according to hotels, we may assume that each hotel would enforce different management policies depending on their operations. Further research should look into the particularities of water consumption patterns, conservation practices and the motivations of different types of hotels in more detail. This study also provided some policy-relevant with rationalization of water consumption. Public programs of support or information could help industries to implement water conservation measures. Our study suggested that public authorities could use social pressure as an important leverage upon the hotel industry during drought periods to promote water conservation. Public pressure could, for example, be increased by simple measures such as publishing data about the water consumption of hotels' establishments during droughts or reporting on which hotel has or has not installed efficient appliances. This study focused on water conservation measures during hotel operation. Future research could focus on conservation measures incorporated in the design and building phase. If adaptation to climate change is to be effective and the hotel industry to improve its sustainability, longer-term and structural changes will be needed, and not only costcutting conservation measures during emergencies, however important these may be. 


\section{Recommendations}

- Spreading awareness to all employees of the hotel by rationalizing the proper use of water and different rationalization methods.

- Making conducting training courses for all sections of the hotel, especially in rationalizing the use of water in all sections of the hotel.

- Making signs and posters about water conservation in hotels for guests to control consumption.

- Producing a special management of water and energy conservation in hotels.

- Using the best means to support best environmental practices with hotels.

- Making a comprehensive checklist for efficient water use.

- Doing a periodic maintenance and follow-up of all water sources within the hotels.

- promoting awareness of the rationalization of the use of water and ways of rationalization through the various media.

- Taking advantage from waste water and reuse it after treatment in other things than drinking in hotels.

\section{References}

Ahram gate, Shuaa securities (2019). The Shape of Water in Egypt - An Opportunity for ORAS and SWDY. Daily newsletter, Egypt.

Bacot, H., McCoy, B. \&Plagman-Galvan, J. (2002). Municipal Commercial Recycling: Barriers to Success. Am. Rev. Public Admin. 32 (2), 145-165.

Baker, M., Davis, E. \& Weaver, P. (2014). Eco-friendly Attitudes, Barriers to Participation and Differences in Behavior at Green Hotels. Cornell Hospitality Quarterly, 55 (1), 89-99.

Barberán, R., Egea, P. \&Gracia-de-Rentería, P. (2013). Evaluation of Water saving Measures in Hotels: A Spanish Case Study. International Journal of Hospitality Management, 34, 181191.

Becken, S., Rajan, R., Moore, S., Watt, M. \& McLennan, C. (2013). White Paper on Tourism and Water, Earth Check Research Institute, Brisbane. 13 (5), 218-226.

Bohdanowicz, P. \&Martinac, I. (2007). Determinants and benchmarking of resource consumption in hotels - Case study of Hilton International and Scandic in Europe. Energy and Buildings, 39(1), 82-95.

Bohdanowicz, P., Simanic, B. \&Martinac, I. (2005). Sustainable hotels-environmental reporting according to green globe 21, Green Globes Canada/GEM UK, IHEI benchmark hotel and Hilton environmental reporting. In Sustainable Building (SB05), 27, 29.

Charara, N., Cashman, A., Bonnell, R. \&Gehr, R. (2011). Water use efficiency in the hotel sector of Barbados. Journal of Sustainable Tourism, 19(2), 231-245.

Choi, H., Jang, J. \&Kandampully, J. (2015). Application of the Extended VBN Theory to Understand Consumers' Decisions about Green Hotels. International Journal of Hospitality Management, 51 (2), 87-95.

Deng, S. \& Burnett, J. (2000). Audit of water consumption in hotels in Hong Kong. Building Services Engineering Research and Technology, 21(3), 209-211.

Deng, S. and Burnett, J. (2002). Water use in hotels in Hong Kong. International Journal of Hospitality Management, 21(1), 57-66. 
Erdogan, N. and Baris, E. (2007). Environmental protection programs and conservation practices of hotels in Ankara, Turkey. Tourism Management, 28(2), 604-614.

Eurostat, MEDSTAT II: 'Water and Tourism' Pilot Study, Eurostat (2009). Luxembourg.

Gabarda-Mallorguí, A., Garcia, X. \&Ribas, A. (2017). Mass Tourism and Water Efficiency in the Hotel Industry: A Case Study. Int. J. Hosp. Manage. 61, 82-93.

Gossel, W., Ebraheem, A. \&Wycisk, P. (2014). A very large scale GIS-Based Groundwater Flow Model for the Nubian Sandstone Aquifer in Eastern Sahara (Egypt, Northern Sudan and Eastern Libya), Hydrogeology Journal, 12 (6), 698-713.

Gössling, S., Peeters, P., Hall, M., Ceron, J., Dubois, G., Lehmann, L. \& Scott, D. (2011). Tourism and Water Use: Supply, Demand and Security. An International Review, Tourism Management, 33 (4), 1 - 15.

Han, H., Lee, M. \& Kim, W. (2018). Antecedents of Green Loyalty in the Cruise Industry: Sustainable Development and Environmental Management. Business Strategy and the Environment, 27 (4), 323-335.

Hoffman, H. (2006). Building Reduced Water and Wastewater Cost into the Design. Austin Water Utility. Austin, Texas. Journal of Consumer Research, 35 (3), 472-482.

Hwang, J. \& Lee, K. (2018). The Antecedents and Consequences of Golf Tournament Spectators' Memorable Brand Experiences. Journal of Destination Marketing and Management, 9, 111, https://doi.org/10.1016/j.jdmm.2017.09.001

Marandu, E., Nkisang, M. \&Haika, J. (2010). Predicting Residential Water Conservation using the Theory of Reasoned Action. Journal of Communi- cation, 1 (2), 87-100.

March, J., Gual, M. \& Orozco, F. (2004). Experiences on Greywater Reuse for Toilet Flushing in a Hotel (Mallorca Island, Spain). Desalination, 164(3), 241-247.

Marta, D. \& David, S. (2015). Water consumption patterns of hotels and their response to droughts and public concerns regarding water conservation: The case of the Barcelona hotel industry during the 2007-2008 episode. Documents d'AnàlisiGeogràfica, 61 (3), 623649.

Meade, B. \& Gonzalez-Morel, P. (2011). Improving Water Use Efficiency in Jamaican Hotels and Resorts through the Implementation of Environmental Management Systems. Journal of Contemporary Water Research and Education, 115(1), 6 -20.

Meade, B. \& Gonzalez-Morel, P. (2011). Improving Water Use Efficiency in Jamaican Hotels and Resorts through the Implementation of Environmental Management Systems. Journal of Contemporary Water Research and Education, 115(1), 6 -20.

Mensah, I. \& Mensah, R. (2013). International Tourists' Environmental Attitude Towards Hotels in Accra. International Journal of Academic Research in Business and Social Sciences, 3 (5), 444-455.

Mensah, I. (2006). Environmental management practices among hotels in the greater Accra region. International Journal of Hospitality Management, 25(3), 414-431.

Millar, M. \&Baloglu, S. (2011). Hotel Guests' Preferences for Green Hotel Attributes. Cornell Hospitality Quarterly, 52 (3), 302-311.

Page, S., Essex, S. \&Causevic, S. (2014). Tourist Attitudes Towards Water Use in the Developing World: A Comparative Analysis. Tour Manage. Perspect. 10, 57-67. 
Scott, C., El-Naser, R. \& Hagan, A. (2009). Facing Water Scarcity in Jordan. Reuse, Demand Reduction, Energy and Trans boundary Approaches to Assure Future Water Supplies, Water Int. 28 (2), 209-216.

Silva-Afonso, A., Rodrigues, F. \& Pimentel-Rodrigues, C. (2011). Water efficiency in buildings: Assessment of its impact on energy efficiency and reducing GHG emissions. Recent Researches in Energy \& Environment. Cambridge: WSEAS Press, 191-195.

Singh, N., Cranage, D. \& Lee, S. (2014). Green Strategies for Hotels: Estimation of Recycling Benefits. 43, 13-22.

Tang, F. (2012). A Study of Water Consumption in Two Malaysian Resorts. World Academy of Science, Engineering and Technology, 68, 1162-1167.

United Nations World Tourism Organization (UNWTO), World Tourism Day (2013), promoting tourism's role in water preservation.

Untaru, E., Ispas, A., Candrea, A., Luca, M. \&Epuran, G. (2016). Predic- Tors of Individuals' Intention to Conserve Water in a Lodging Context: The Application of an Extended Theory of Reasoned Action. International Journal of Hospitality Management, 59 (5), 50-59.

Wyngaard, A. \& de-Lange, R. (2013). The Effectiveness of Implementing eco Initiatives to Recycle Water and Food Waste in Selected Cape Town Hotels. Int. J. Hosp. Manage, 34, 309-316. 